\title{
UREJANJE TRIGLAVSKEGA NARODNEGA PARKA ZA OBISKOVALCE V LUČI CILJEV IN NAMENOV USTANOVITVE NARODNEGA PARKA
}

\author{
mag. Martin Šolar \\ Triglavski narodni park \\ Ljubljanska cesta 27, SI-4260 Bled \\ e-mail: martin.solar@tnp.gov.si
}

Strokovni članek

COBISS 1.04

\section{Izvleček}

Zavarovana območja narave so kronski dragulj vsega naravovarstvenega dela, ustrezno varovanje pa je možno le s primernim upravljanjem zavarovanih območij. Upravljavskih nalog je v Triglavskem narodnem parku glede na pestrost in raznolikost alpskega prostora veliko, urejanje parka za obiskovalce je le ena od pomembnih upravljavskih nalog. V drugem delu prispevka govorimo prav o upravljavskih pristopih in stanju na terenu pri urejanju parka za obiskovalce.

Ključne besede: narodni park, cilji upravljanja, urejanje parka, informacijske table

\section{PROVIDING VISITOR INFRASTRUCTURE IN THE TRIGLAV NATIONAL PARK IN THE LIGHT OF THE OBJECTIVES AND PURPOSES OF ESTABLISHING A NATIONAL PARK}

\begin{abstract}
Protected natural areas are the crown jewels of nature conservation efforts, and the only way to ensure proper nature protection is through good management of protected areas. Although management tasks required on account of the diversity and variety of the Alpine territory are too many to list, visitor infrastructure is only one of important management activities. The second part of the paper discusses management approaches and the existing state of visitation infrastructure in the park.
\end{abstract}

Key words: national park, management objectives, visitor infrastructure, information boards 


\section{UVOD}

Kaj je narodni park? Zakaj je bil ustanovljen Triglavski narodni park (TNP)? Katere so upravljavske naloge $\mathrm{v}$ parku in kaj naj bi delala upravljavska organizacija? To so pogosta vprašanja $v$ širši in tudi strokovni javnosti. Na prvi pogled enostavni odgovori na navedena vprašanja so prazni brez dodatne strokovne razlage o ciljih in namenih narodnih parkov.

Posebno vredni deli narave, ki jih lahko imenujemo naravne znamenitosti, naravna dediščina ali naravne vrednote, imajo (na nek način) antropogeni izvor. Človek ni vplival na njihovo pojavljanje, je bil pa tisti, ki je del narave označil kot posebno vreden, kot dediščino, oziroma določil tiste dele narave, ki so spoznani kot naravne vrednote. Deli narave, spoznani kot naravne vrednote, so pravzaprav le zelo majhen delež vsega naravnega okolja. Praviloma se v tisti pokrajini, kjer je naravnih vrednot največ, najprej pojavijo težnje po zavarovanem območju, težnje po ustanovitvi parka. Naravovarstvena stroka je v glavnem že prešla iz točkovnega varstva naravnih vrednot na celostno varovanje narave $\mathrm{v}$ obliki zavarovanih območij oziroma v obliki varstva habitatov. Prav v celostnem varovanju je največji pomen zavarovanih območij za varstvo narave. Točkovno varstvo ali ozko varstvo lokalitete naravne vrednote ni zagotovilo za učinkovito varovanje narave, predvsem je težko preprečevati posredne vplive okolja (Šolar 2000).

\section{KAJ JE NARODNI PARK?}

Po vsem svetu so uveljavljene različne oblike zavarovanih območij, poimenovanje pa ni enotno. Najbolj razširjene oblike in imena so naravni rezervat, gozdni rezervat, naravni spomenik, narodni spomenik, narodni park, naravni park, regijski park, krajinski park, zavarovana pokrajina in območje divjine. Glede na naravovarstveni in nacionalni pomen so narodni parki tista oblika zavarovanega območja, kjer je ohranjanje in varstvo narave na najbolj neposreden način približano javnosti.

V nadaljevanju navajamo nekatere misli, opise in definicije za narodni park, ki jih zasledimo pri različnih avtorjih.

Definicija, vloga, namen in cilji narodnega parka so v literaturi različni, pogledi na narodni park pa so se spreminjali tudi glede na čas in razvoj samega naravovarstva. To velja tako za svetovne, kot tudi domače, slovenske razmere. Anko (2001) npr. ugotavlja, da dolga vrsta pravnih aktov (veljavnih na območju Slovenije), ki zadevajo narodne parke, vzroka za njihov obstoj ne skuša utemeljevati.

Ko je ob koncu 19. st. v Severni Ameriki zaživela ideja o ustanavljanju narodnih parkov, je bil njen cilj zavarovati in ohraniti območja v njihovem naravnem stanju. Naravno stanje pomeni nedotaknjeno pokrajino brez vpliva človeka. Dandanes se zavedamo, da je ohranitev pokrajine v povsem naravnem stanju skoraj nemogoča, zato je cilj upravljanja in varovanja v narodnih parkih ohranjati stanje, ki je blizu naravnemu (Larsson 1993). To trditev lahko dopolnimo s komentarjem, da ohranjati povsem naravno stanje izjemoma omogoča le izločanje strogih naravnih rezervatov.

Narodni parki se uvrščajo med območja zavarovane narave, ki jih družba daje pod neposredno varstvo, da bi se ohranili nekateri deli narave zaradi splošnih družbenih interesov. 
To so celovita območja z visoko stopnjo varovanja, imajo pa več namenov: znanstvenega, vzgojno-izobraževalnega in kulturnega (Vidaković 1997).

Narodni parki v Evropi predstavljajo skoraj celoten spekter naravnih pokrajinskih tipov in so splošno priznan ter sprejet instrument za varovanje pristne narave. Večinoma so visoko cenjeni, milijoni ljudi iščejo v njih doživljanje narave, izobraževanje in sprostitev. Prispevajo značilno velik delež k varovanju evropske naravne dediščine (Güthler in sod. 1998). Podobno je tudi drugod v razvitem svetu, predvsem v Združenih državah Amerike in Kanadi.

Eden najuglednejših evropskih naravovarstvenih strokovnjakov Hans Bibelriether meni, da so narodni parki najpomembnejša kategorija zavarovanih območij, ki zagotavlja varstvo narave ne le v posameznih deželah, temveč za celotno Evropo in svet. V narodnih parkih je narava zavarovana $v$ precej širšem smislu kot je le varstvo atraktivnih vrst rastlin in živali. V parkih se varuje celotna raznolikost življenja, življenjskih združb in ekosistemov v njihovem naravnem razvoju. Glavne naloge parkov so določene v 'Smernicah za kategorije upravljanja z zavarovanimi območji' organizacije IUCN (ang. International Union for Conservation of Nature). Po teh smernicah morajo narodni parki zavarovati naravne življenjske združbe pri njihovem nemotenem naravnem razvoju brez človeškega poseganja v smislu vodenja, uporabe ali celo izkoriščanja teh območij. S tem se zagotovi nadaljevanje zdaj že milijone let trajajoče evolucije. K naravnemu razvoju ekosistemov štejejo tudi včasih nenavadne, celo grozljive slike - plazovi, hudourniki in viharji ali posledično masovno razmnoževanje insektov v gozdovih. V narodnih parkih velja princip - 'pustiti naravi biti narava'. Istočasno pa parki v svojem poslanstvu nudijo ljudem, ki jih zanima in navdušuje vse naravno, možnost, da doživijo prvinsko naravo, divjino, raznolikost in enkratnost naravnih pojavov (Bibelriether 2001). Navedene misli in pogledi na narodni park sodijo med sodobne in za današnje upravljanje narodnih parkov najbolj uporabne.

Ker skrajšana definicija za IUCN kategorijo II - narodni park opredeljuje narodni park kot zavarovano območje namenjeno varstvu ekosistemov in rekreaciji, je ta termin v svetu tesno povezan z na naravo vezanim turizmom (Eagles 2001). Ta zelo splošna oznaka, ki že nakazuje razmerja med varstvom narave in rekreacijo, pa je lahko za osnovne naravovarstvene cilje že nevarna. Precej bolj smiselno so termin narodni park avtorji opredelili v smernicah 'Razvoj narodnih parkov in zavarovanih območij za turizem'. Pojem narodni park je uporabljen kot naravno območje, ki ima določen tip mednarodno uveljavljenih varstvenih standardov in kjer je dovoljena neka določena stopnja obiskovanja in turizma (McNelly in sod. 1992).

Tudi pri slovenskih avtorjih najdemo različne poglede in definicije za narodni park. A. Piskernik (1962) je v duhu časa, v katerem je bila vodilna slovenska naravovarstvenica, zapisala, da narodni parki niso sami sebi namen, ampak služijo znanosti in delovnemu človeku za pouk in oddih. Za ljudi ustvarjamo otoke miru, rekreacijske in narodne parke, kjer se bo človek v lepi, zavarovani in negovani naravi razvedril in si pridobil novih telesnih in duševnih sil za svoje nadaljnje udejstvovanje.

V času nastajanja današnjega TNP sta se soočali dve zasnovi, prva izrazito naravovarstvena, druga bolj turistično-okoljska. Ureditev parka tako temelji na gospodarnem upravljanju, vendar $\mathrm{z}$ omejitvami v osrednjem delu, da se zagotovi ohranitev naravnih vrednot. V zunanjem pasu pa je dovoljeno kmetovanje in gozdarjenje, sonaravni turizem in rekreacija ob upoštevanju lastniških pravic in dopustne obremenitve narave (Lah 2001). 
V zgodovini sta se verjetno vedno pojavljala dva osnovna motiva, zaradi katerih je človek želel zavarovati posamezne dele narave: izjemnost neke pokrajine ali njenega dela in ogroženost zaradi človekovih posegov. Tako je skupni osnovni cilj zavarovanih predelov po vsem svetu v prvi vrsti varovanje narave, ponekod pa tudi ohranitev izjemnih kulturnih vrednot vsenarodnega in mednarodnega pomena. Če gre za delno poseljene predele, pa tudi zagotavljanje ustreznih možnosti za razvoj naselij in preživetje tamkajšnjega prebivalstva (Lukan Klavžer in Šolar 1996).

Poleg zakonov, konvencij, standardov, smernic in navodil so v svetu uveljavljena tudi nenapisana splošna načela o tem, kaj je narodni park in kakšen naj bi bil. Ta načela so botrovala ustanavljanju prvih narodnih parkov v prejšnjem stoletju in do druge svetovne vojne. Ko so ustanavljali prve parke v Ameriki in Evropi in ko so leta 1924 uresničili zamisel o TNP in jo leta 1961 razširili, niso imeli nobenega zakona ali konvencije. Priznavali so le načela in imeli veliko hotenje uresničiti ta načela. Po teh nenapisanih načelih je narodni park prostor izjemnih lepot in vrednot narodnega, državnega in mednarodnega pomena, nekakšno posvečeno območje, $v$ katerem skušamo naravo in njene lepote ohraniti tako, da jo pustimo pri miru takšno kot je, je ne spreminjamo, ne izkoriščamo naravnih dobrin, zavarovano naravo le obiskujemo in jo doživljamo, peš in brez hrupnih ali drugače motečih prevozov (Bizjak 2001).

\section{CILJI UPRAVLJANJA V TRIGLAVSKEM NARODNEM PARKU}

Osnovni cilj in namen ustanovitve TNP je ohranitev izjemnih naravnih in kulturnih vrednot, varovanje rastlinskega in živalskega sveta, ekosistemov ter značilnosti nežive narave. Hkrati je namen TNP, da se skladno s primarnimi varstvenimi cilji in naravnimi danostmi zagotovi možnosti za naravi in kulturni krajini prijazen trajnostni razvoj in življenje ljudi v parku in njegovi neposredni bližini. Namen parka je tudi nuditi možnost za doživljanje narave, kulturnega izročila in duhovnih vrednot tega izjemnega alpskega prostora.

Narodni parki pomenijo že sami po sebi dovolj visoko raven zavarovanja s poudarjeno nacionalno vrednoto. Vrednota narodnega parka je v splošnem v zavesti ljudi zelo cenjena, $\mathrm{v}$ mnogih primerih pa je mnenje drugačno med upravljavci in prebivalci oziroma lastniki zemljišč v narodnem parku. Pri upravljanju narodnih parkov gre pravzaprav le za dve možni poti. V prvem primeru gre za pošteno naravovarstveno in parkovno usmeritev, ki trdno in odločno vztraja na uveljavljanju upravljavskih ciljev, ki edini zagotavljajo varstvo, ohranitev in sonaravni razvoj v skladu s cilji zavarovanja in upravljanja. Druga pot pa je le navidezno varstvo, kjer se za tablo in napisom narodni park skrivajo vse mogoče aktivnosti, narodni park pa v takih primerih pomeni le kuliso za nekatere druge cilje, oziroma dovoljuje kompromise do take mere, da so pravi parkovni upravljavski cilji povsem v ozadju.

Res je, da so cilji upravljanja v narodnih parkih lahko specifični glede na različne fizičnogeografske in biotske danosti, glede na lastništvo in interese, vendar mora obstajati nek skupni imenovalec. Celostno varovanje narave v okviru zavarovanih območij je edino resnično zagotovilo za ohranitev naravnih vrednot in ekosistemov. Tako varovanje lahko dosežemo samo na osnovi jasno določenih ciljev upravljanja in varstva najbolj vrednih delov narave ter kulturne krajine s kulturno dediščino. 
V osrednjem območju je osnovni cilj upravljanja varstvo narave, raziskovanje, izobraževanje ter usmerjeno obiskovanje. Ti cilji v osrednjem območju zahtevajo izločitev izkoriščanja naravnih virov ter zagotovitev nemotenega razvoja ekosistemov brez vpliva človeka. Izločitev izkoriščanja naravnih virov pomeni omejitev oziroma prepoved gospodarskih dejavnosti, kot so kmetijstvo, gozdarstvo, vodno gospodarstvo, izkoriščanje rudnin in mineralov ter lov in ribolov. Prav tako niso dopustni, oziroma so zelo omejeni posegi v prostor, spreminjanje oblikovitosti površja, gradnja neparkovnih objektov, izvajanje rekreacijskih dejavnosti v komercialne namene in športna tekmovanja. Upravljanje osrednjega območja temelji na varstvu zavarovanega in iz gospodarjenja izločenega območja, na urejanju in opremljanju za obiskovalce ter na usklajevanju pri urejanju turistične infrastrukture na robu oziroma ob meji zavarovanega območja. V osrednjem območju se mora zagotoviti možnost obiskovanja za kulturne, rekreacijske, vzgojno-izobraževalne in znanstvenoraziskovalne namene v obsegu in na način, ki ne bo v nasprotju z osnovnimi naravovarstvenimi cilji.

V robnem območju narodnega parka pa so ukrepi za varstvo in razvoj usmerjeni k vzdrževanju in negi kulturne krajine ter k spodbujanju tradicionalnih dejavnosti, ki ohranjajo značilno identiteto in zagotavljajo trajnost naravnih dobrin. Tu mislimo predvsem na trajnostni regionalni razvoj s poudarkom na biološkem kmetovanju, kmetijsko-okoljskih programih, razvoju in ohranitvi domače obrti, gozdarstvu, turizmu na kmetijah in sploh spodbujanju naravi prijaznega turizma $\mathrm{z}$ rekreacijo. Kulturna krajina je v alpskem prostoru neločljivo povezana z neokrnjeno naravo. Prav izjemna in značilna kulturna krajina, ki jo je skozi stoletja soustvarjal človek, je ogledalo TNP. Glavni cilj in namen upravljanja v robnem območju je s trajnostno rabo ohraniti podobo kulturne krajine.

Iz predhodno navedenega je razvidno, da narodne parke - TNP pri tem ni izjema ustanavljamo tudi za namene vzgoje in izobraževanja ter obiskovanja (turizem in rekreacija). Obiskovalci so stalnica tudi v TNP, edinem tovrstnem zavarovanem območju v Sloveniji. Pravzaprav velika večina obiskovalcev prihaja v TNP zaradi gora in ne zaradi parka samega. Čeprav obiskovanje nedvomno ima mesto v narodnih parkih, je obisk potrebno urejati, usmerjati in načrtovati. Urejanje parka za obiskovanje sodi med pomembne cilje in namene narodnega parka ter posledično med pomembne naloge upravljavca zavarovanega območja javnega zavoda TNP.

\section{USMERJANJE OBISKOVALCEV IN PARKOVNA INFRASTRUKTURA}

Pri načrtovanju usmerjanja obiskovalcev sledimo splošnim ciljem in razvojni strategiji narodnega parka. Dejstvo je, da so nekatera območja ali prostorsko manjše enote (posamezne naravne vrednote, objekti kulturne dediščine, razgledne točke ipd.) za ljudi bolj zanimive od drugih, pa naj bodo na zavarovanih območjih ali zunaj njih. Obisk teh lokacij je pogostejši in številčnejši - ponekod že od nekdaj, drugod v zadnjih letih, ko se pomen obiskovanja parka, turizma in gibanja v naravi povečuje. Te t. i. 'vroče točke' je težko ali nemogoče izolirati od obiskovalcev in jih prepustiti strogemu varstvu. Bolje je aktivno urediti posamezne lokacije in usmerjati obiskovalce. S tem tisto, kar je občutljivejše ali vrednejše, lažje varujemo in obenem nadziramo število obiskovalcev na določenem območju (Pretner in Šolar 2006). 
Učinkovito varovanje ter obenem zagotavljanje potreb obiskovalcev je možno z dobro urejeno parkovno infrastrukturo na terenu, $v$ virtualnem svetu so nam v pomoč spletne strani, sicer pa opisi v vodnikih, članki, zloženke ipd. Veliko pa k usmerjanju in informiranju lahko pripomorejo tudi parkovni uslužbenci.

Urejanje parka za obiskovalce ima več ravni:

- informacijska središča, postaje in točke;

- opremljanje na terenu;

- literatura;

- internetne strani;

- vodeni izleti.

Vse ravni so med seboj povezane in pomenijo možnost doživetega, informativnega in poučnega spoznavanja zavarovanega območja. V nadaljevanju pa se osredotočamo predvsem na področje opremljanja na terenu.

Slika 1: Informacijski stebriček z usmerjevalnimi tablicami (foto: M. Šolar)

Figure 1: Information post with orientation signs (photo: M. Šolar)

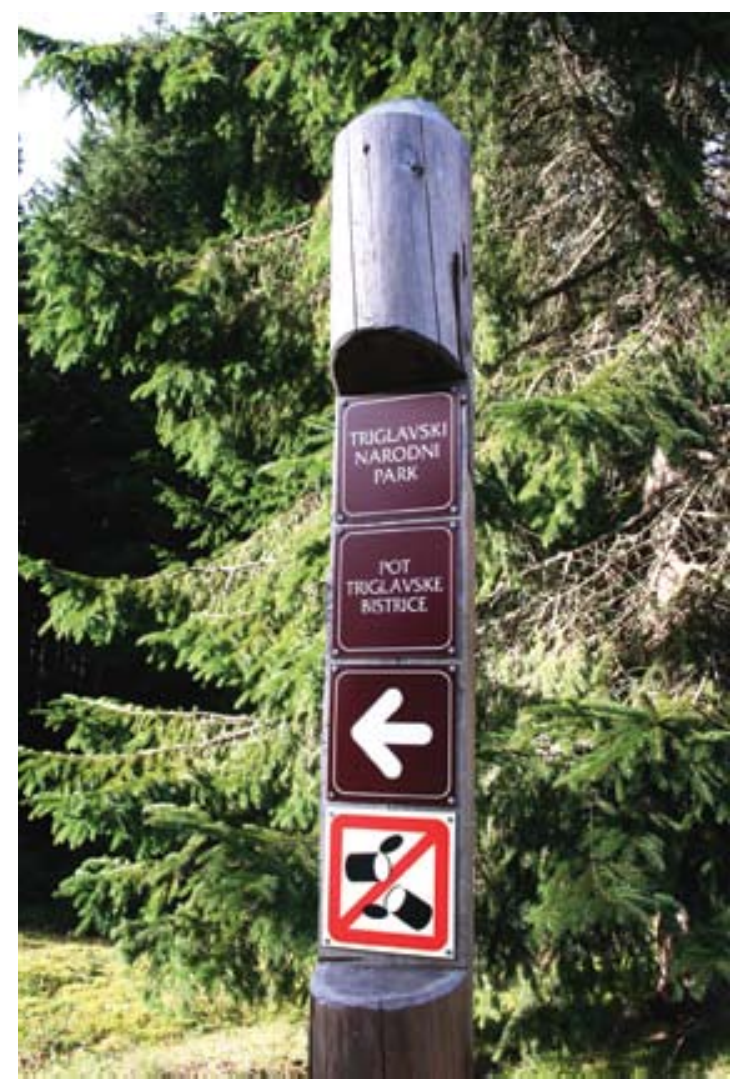




\section{I Informacijske točke na terenu in učne poti}

Pestrost in zanimivost narave in kulturne krajine s kulturno dediščino, ki s svojimi pojavi izstopa na posameznih območjih TNP, sta vzrok za urejanje informacijskih točk in učnih poti na terenu. Vsako informacijsko mesto mora obiskovalcu ponuditi nedvoumno sporočilo o naravi na zavarovanem območju, ravnanju v njem ali o bogati kulturni dediščini tega območja. Še več, informacijske točke morajo postati orodje za razvijanje parkovnega turizma, ki bo temeljil na usklajenem okoljskem, socialnem in gospodarskem razvoju. Tako bo poleg narave ohranjal tudi kulturno dediščino, ki je možna le z ohranjanjem prebivalstva oziroma zagotavljanjem tudi njihovega preživetja.

Informacijske točke imajo prednostno informativno vlogo. Tej sledi predvsem izobraževalna, doživljajska in, nenazadnje, turistična funkcija. Parkovna infrastruktura vse bolj postaja del turistične infrastrukture predvsem tam, kjer je zavarovano območje del turistično prepoznavne destinacije.

Cilji in pomeni informacijskih točk ter parkovnih poti v TNP so predvsem:

- povezovanje več naravnih vrednot oziroma objektov kulturne dediščine v celoto;

- usmerjanje obiskovalcev in posreden prispevek $\mathrm{k}$ ohranitvi narave;

- predstavitev vrednot/objektov in splošnih parkovnih usmeritev;

- dodatna ponudba $v$ prostoru (npr. za turizem).

Informacijske točke in poti se nahajajo:

- $\quad$ kjer je potreba (pogost, številčen obisk);

- kjer je večja gostota naravnih vrednot oziroma objektov kulturne dediščine;

- zunaj občutljivih območij (rezervati, življenjski prostori ogroženih vrst, posebna ohranitvena območja);

- na (lahko) dostopnih mestih (bližina cest);

- na predhodno urejenih mestih;

- v bližini dodatne ponudbe (parkirišče, sanitarije, gostišče ...).

Informacijske točke na terenu in parkovne poti TNP bi lahko glede na dolžino in obseg razdelili v štiri skupine:

- posamezne informacijske table;

- informacijske točke na eni lokaciji;

- širše informacijske točke ali krajše učne oziroma naravoslovne poti;

- prave parkovne poti.

Posamezne informacijske table s pojasnevalnimi vsebinami se praviloma nahajajo v neposredni bližini ali na razgledni točki pri posamezni naravni znamenitosti ali objektu kulturne dediščine.

Informacijske točke 'na lokaciji' so opremljene vsaj z dvema ali več informacijskimi oznakami - praviloma informacijskimi pojasnjevalnimi tablami - in ne sodijo v sklop parkovnih poti.

Širše informacijske točke ali krajše učne oziroma naravoslovne poti se praviloma nanašajo na en, prostorsko manjši naravni pojav - naravno vrednoto. Ta je med krajšim spre- 
hodom predstavljena $\mathrm{z}$ več informacijskimi objekti ali pa so informacijske table le na začetku in koncu odseka poti, kjer je zanimivost.

Parkovne poti so najdaljše in v primerjavi s krajšimi ponujajo več - predvsem glede doživljanja narave in kulturne krajine in tudi za rekreacijo. Sicer pa tako krajše učne oziroma naravoslovne kot prave parkovne poti zadoščajo splošnim ciljem poti (povezovanje več naravnih vrednot oziroma objektov kulturne dediščine v celoto, usmerjanje obiskovalcev in posredno prispevanje $\mathrm{k}$ ohranitvi narave, predstavitev vrednot/objektov in splošnih parkovnih usmeritev, dodatna ponudba v prostoru).

\section{INFORMACIJSKE TABLE V TRIGLAVSKEM NARODNEM PARKU - RAZVOJ IN STANJE}

Označevanje in opremljanje narodnega parka je dinamičen in razvojen proces. Razvili smo na nek način originalen in edinstven pristop, v katerem so zajete avtorske ideje J. Bizjaka, dolgoletnega direktorja TNP. Ena prvih nalog takoj po ustanovitvi parka je bila postavitev mejnih oznak. Na vseh pomembnejših, predvsem cestnih vstopih v TNP so bile nameščene velike vstopne table v obliki kozolca z napisom »Triglavski narodni park (Šolar 2001). Table so po več kot petindvajsetih letih oblikovno in vsebinsko nekoliko zastarele, vendar so vzdrževane in še vedno predstavljajo nekakšen simbol parka. Ne preganja jih zob časa, temveč novodobni predpisi s področja cestne signalizacije, ki narekujejo postavitev drugačnih mejnih tabel.

\section{Slika 2: Vstopna tabla TNP na meji parka (foto: J. Mihelič)}

Figure 2: TNP entrance panel at park boundary (photo: J. Mihelič)

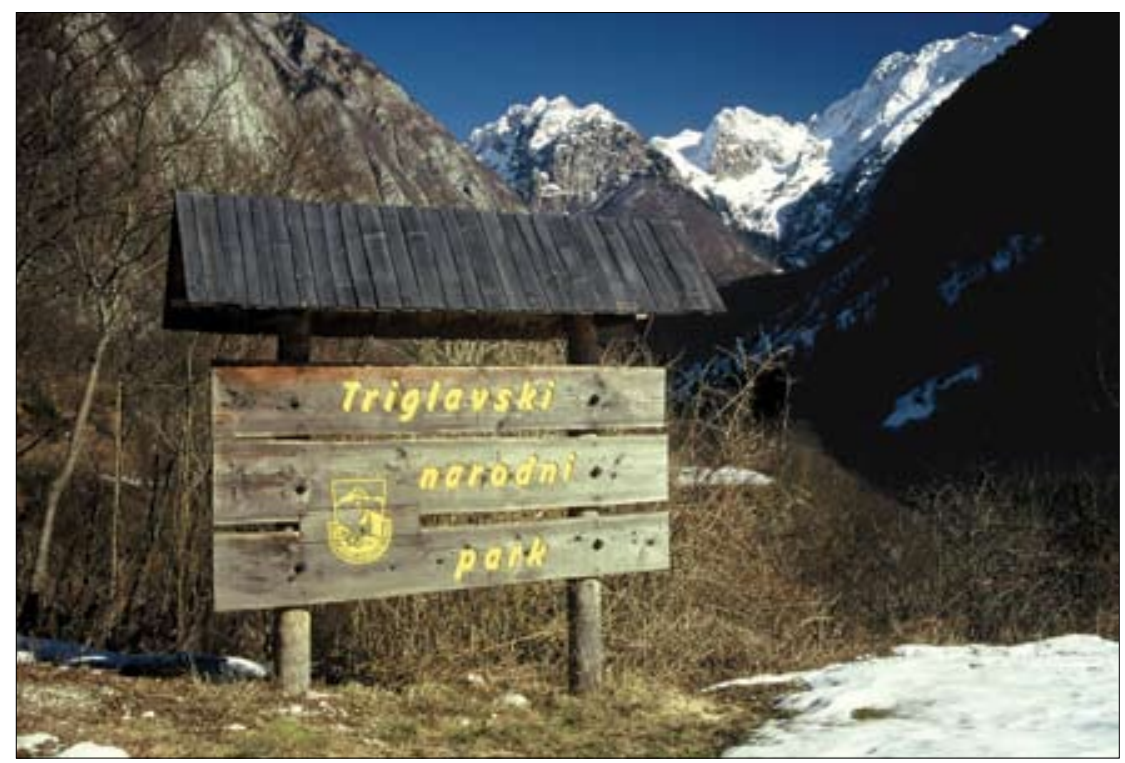


Naslednji korak označevanja v TNP je bil postavitev tabel, ki označujejo osrednje območje TNP. Table so postavljene ob cestah in poteh na meji med robnim in osrednjim območjem parka. V začetku devetdesetih let je bil storjen naslednji, že bolj moderen in učinkovit korak pri opremljanju TNP. Na najbolj obremenjenih in obiskanih lokacijah (npr. Vrata, Vršič, Mangartsko sedlo, Pokljuka, Bohinjsko jezero itd.) so bile postavljene splošne informacijske table. Na tablah je shema parka in grafični prikaz (piktogram) pravil obnašanja oziroma prepovedi v parku. Hkrati so bili v sklop informacijskih tabel v TNP uvedeni tudi informacijski stebrički z manjšimi tablicami. Za nosilni stebriček je uporabljen star, že uporabljen les ali pa lesni sortimenti, ki bi sicer bili odpadek, oziroma se jih ne da uporabiti v druge namene. V prvi fazi so bili postavljeni stebrički s prepovedmi, kasneje pa so bile dodane tudi druge informacije, kot npr. usmerjevalne in označevalne table za naravne znamenitosti ter planinske oznake. V TNP je postavljenih več kot 200 informacijskih stebričkov. Ti t.i. 'totemi' so postali priljubljen simbol parka tako med obiskovalci kot prebivalci parka. Sočasno s postavitvijo splošnih informacijskih tabel in informacijskih stebričkov se je pričelo postavljati še informacijske označevalne in pojasnjevalne table za naravno in kulturno dediščino.

Sledile so pojasnjevalne (informacijske) table za posamezne naravne znamenitosti ali objekte kulturne dediščine (izvir Soče, slap Savice, Dvojno jezero, Martuljški slapovi in druge) ter urejanje krajših in daljših parkovnih poti. V zadnjem času je naš cilj predvsem smiselno funkcionalno povezovanje informacijskih točk na terenu ter vzdrževanje vse te infrastrukture. Nenazadnje velja tudi omeniti, da so bila besedila vseh informacijskih tabel sprva le v slovenskem jeziku, v zadnjih letih pa smo večino tabel zamenjali z besedilom $\mathrm{v}$ slovenskem ter tudi angleškem jeziku.

$\mathrm{V}$ zadnjem desetletju našo parkovno infrastrukturo razvijamo s ciljem povezovanja posameznih lokacij v zaokrožene celote - gre za urejanje informacijskih točk na terenu ter krajših in daljših parkovnih (tematskih) poti. Parkovne poti so urejene v Trenti, Vratih, na Pokljuki, v Radovni in Tolminskih koritih. V naslednjih letih ne načrtujemo velikega razmaha obstoječe mreže poti z izjemo Bohinja, kjer prave parkovne poti še ni.

Parkovna infrastruktura, še posebej vse vrste informacijskih tabel, je skrbno popisana in vnešena $v$ naš računalniški geografski informacijski sistem. Vseh objektov infrastrukture v TNP je prek 1700, samo informacijskih tabel z nekimi vsebinami je 117. Ali jih je dovolj, so dovolj razumljive, so vsebine prave? V poletni sezoni 2008 smo v TNP izvedli obsežno raziskavo med obiskovalci TNP. Eno od vprašanj v anketi je bilo: »Ali je v parku dovolj informacijskih tabel?«. Velika večina ( $83 \%$ od 313 vprašanih) je odgovorila, da je tabel dovolj. Podobno so anketiranci odgovorili na vprašanje: »Ali so informacijske table dovolj jasne?«. Na to vprašanje je pritrdilno odgovorilo 79 \% vprašanih! Kaj pa primernost vsebin? Katere naravne ali kulturne znamenitosti so najbolj pomembne, česa je več? Večno vprašanje!

Med vsebinami na 117 različnih informacijskih tablah izstopajo:

- $\quad$ splošne table o TNP in parkovnih poteh (20 tabel);

- table, kjer se kombinirano prepletata geomorfološka in hidrološka vsebina (19 tabel);

- vsebine kulturne dediščine oziroma etnologije in zgodovine (17 tabel);

- biološke vsebine (15 tabel);

- tehnična dediščina (13 tabel); 
- geomorfološke vsebine (12 tabel);

- gozdarske vsebine (12 tabel);

- hidrološke vsebine (9 tabel).

Temu velja dodati, da se vsebine na mnogih tablah prepletajo, kar je tudi logično in razumljivo, saj so naravoslovni elementi v naravi med seboj povezani in prepleteni.

Bolj podrobno o vsebinah govori tudi preglednica informacijskih tabel na poteh (preglednica 1), ki jih je sam ali v sodelovanju z nekaterimi drugi upravljavci uredil TNP. Tudi na informacijskih točkah na poteh gre v mnogih primerih za preplet različnih vsebin. Glede na osnovno ime informacijske točke smo poskušali določiti osnovno vsebino posamezne table. Izjema so table, kjer se enakovredno prepleta hidrološka in geomorfološka vsebina in je tak tip kombinirane table samostojno zastopan $\mathrm{v}$ preglednici.

Preglednica 1: Vsebine na informacijskih točkah parkovnih poti

Table 1: Contents presented on the information boards along park trails

\begin{tabular}{|c|c|c|c|c|c|c|}
\hline Ime poti & \multirow{2}{*}{$\begin{array}{c}\text { Soška } \\
\text { pot } \\
\text { (Trenta) }\end{array}$} & \multirow{2}{*}{$\begin{array}{c}\text { Pot } \\
\text { Triglavske } \\
\text { Bistrice } \\
\text { (Vrata) }\end{array}$} & \multirow{2}{*}{$\begin{array}{c}\text { Pokljuška } \\
\text { pot }\end{array}$} & \multirow{2}{*}{$\begin{array}{l}\text { Učna pot } \\
\text { Barje } \\
\text { Goreljek }\end{array}$} & \multirow{2}{*}{$\begin{array}{c}\text { Kolesarska } \\
\text { pot } \\
\text { Radovna }\end{array}$} & \multirow{2}{*}{$\begin{array}{c}\text { Pot po } \\
\text { Tolminskih } \\
\text { koritih }\end{array}$} \\
\hline $\begin{array}{l}\text { Vsebina } \\
\text { informacijske table }\end{array}$ & & & & & & \\
\hline Splošna tabla o poti* & 2 & 3 & 1 & 1 & 2 & 1 \\
\hline Splošna o TNP & 2 & & & & & \\
\hline Razgledna tabla & 2 & & & & & \\
\hline Hidrologija & 1 & 2 & & 1 & & 2 \\
\hline Geomorfologija & 2 & 4 & & & 1 & 1 \\
\hline $\begin{array}{l}\text { Hidrologija / } \\
\text { geomorfologija }\end{array}$ & 3 & 2 & 1 & 1 & 2 & 2 \\
\hline Botanika & 2 & 2 & & 5 & & 1 \\
\hline Gozdarstvo & 1 & 4 & 3 & & 1 & \\
\hline Živalstvo & 2 & 4 & & 3 & & 1 \\
\hline Etnologija & 2 & 1 & 2 & 1 & 1 & \\
\hline $\begin{array}{l}\text { Kulturna dediščina } \\
\text { (ostalo) }\end{array}$ & 2 & 1 & & & 4 & \\
\hline Tehnična dediščina & 2 & & 1 & 1 & 2 & 1 \\
\hline Skupaj & 22 & 23 & 8 & 13 & 13 & 9 \\
\hline
\end{tabular}

* Splošne table o posamezni poti so praviloma postavljene na začetku in koncu poti, oziroma dodatno še na lokaciji, kjer se ustavi veliko število obiskovalcev. Na teh tablah so splošni opisi območja, koder poteka pot (na kratko so zajete vse naravoslovne vsebine) in kratek opis poti.

Soška pot je najstarejša parkovna pot v TNP; vodi od izvira Soče do meje parka pred Bovcem in se tam navezuje na sistem bovških turističnih poti. Soška pot povezuje dolino Trente in večji del poteka vzdolž reke Soče. Največ informacijskih točk je v zgornjem delu doline, saj se pot neposredno navezuje na Informacijsko središče TNP Dom Trenta Na Logu 
v Trenti. Informacijske točke na poti so namenjene enakomernemu informiranju o naravnih in kulturnih znamenitostih doline, pri čemer so v pot vključene najbolj poznane in atraktivne točke - izvir Soče, Kugyjev spomenik, korita Mlinarice ter Soška korita. Pot je bila dokončno urejena leta 2005, upravljavec poti je TNP.

\section{Slika 3: Informacijska tabla na Poti Triglavske Bistrice v Vratih (foto: A. Zdešar)}

Figure 3: Information board along the Triglavska Bistrica trail in Vrata valley (photo: A. Zdešar)

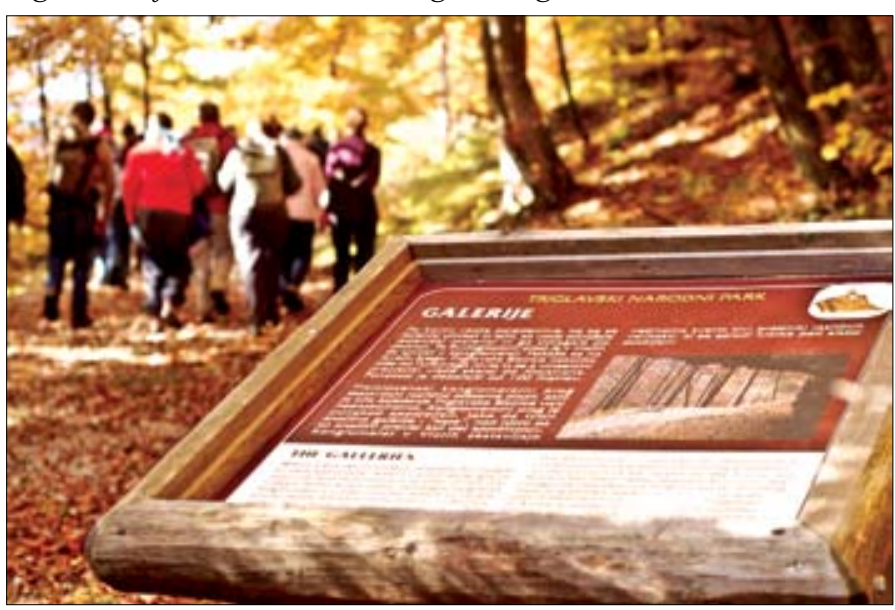

Pot Triglavske Bistrice v dolini Vrata je bila prvotno urejena kot Naravoslovna učna pot Vrata. Vodi iz Mojstrane v zatrep doline, dobršen del poteka po obstoječi planinski poti. Prvotno je pot povezovala predvsem gozdove in njihove zanimivosti, po prenovi leta 2006 pa so na poti porazdeljene informacijske točke o naravnih znamenitosti (prevladujejo geomorfološke, gozdarske in vsebine o živalstvu), kulturne dediščine je v dolini manj. Najbolj poznane točke v dolini, slap Peričnik, Galerije ter zatrep pod Severno triglavsko steno, so del poti. Partner pri urejanju Poti Triglavske Bistrice je Planinsko društvo Dovje Mojstrana, upravljavec pa je TNP.

Pokljuška pot je parkovna in gozdarska pot, ki je nastala s sodelovanjem TNP in Zavoda za gozdove Slovenije. Povezuje gozdove, planine in nekatere zanimivosti. Namenjena je gozdarskim ekskurzijam in drugim skupinam ter usmerjanju obiskovalcev na planoti. Na informacijskih točkah je poudarek na gozdarskih vsebinah, tudi etnološki informacijski tabli sta delno povezani z osnovno temo (oglarjenje, planinsko pašništvo). Pot je bila urejena leta 2003, upravljavec je TNP, strokovno sodelovanje zagotavlja Zavod za gozdove.

Učna pot Barje Goreljek je nastala v okviru projekta LIFE - Šotna barja v TNP. Cilj ureditve učne poti na barju Goreljek je preusmerjanje obiskovalcev ter raznih skupin ekskurzij na to barje, kjer so zgoščene informacije o barjanskem ekosistemu. Tovrstne informacije prevladujejo na informacijskih tablah, poleg bioloških vsebin so prisotne še hidrološke in etnološke. Pot na barju Goreljek je bila urejena leta 2003 in se smiselno vklaplja v daljšo Pokljuško pot. Pot upravlja TNP. 
Kolesarska pot Radovna je nastala na pobudo Osnovne šole Gorje, ki je za idejo o kolesarski tematski poti po Radovni dobila nagrado Turistične zveze Slovenije. Radovna je izjemno zanimiva dolina v robnem območju TNP, kjer se narava prepleta s kulturno krajino in njeno kulturno in tehnično dediščino. Prav na tem je tudi poudarek pri informacijskih tablah. Reka Radovna je rdeča nit poti, ki se konča pri Pocarjevi domačiji - kulturnem spomeniku državnega pomena. Pot je bila odprta leta 2004, upravljavec je TNP.

Tolminska korita so naravna znamenitost in osrednja turistična atrakcija na Tolminskem. Na pobudo upravljavca poti v koritih, Lokalne turistične organizacije Sotočje iz Tolmina, je pri urejanju območja TNP prevzel nalogo postavitve informacijskih tabel. Na krajši krožni poti skozi korita je postavljenih nekaj tabel, ki obveščajo o osrednjih zanimivostih - sotočju v koritih, termalnem izviru ter Skakalcah in Medvedovi glavi, ter tudi o nekaterih drugih posebnostih območja. Informacijske table so bile nameščene v letu 2006.

\section{ZAKLJUČEK}

Izjemnost TNP je v tem, da takega števila in pestrosti vseh naravnih in kulturnih vrednot nikjer drugje v Evropi ne najdemo na tako enotno zaokroženem prostoru kot so Julijske Alpe v Sloveniji, te pa so praktično v celoti zavarovane kot TNP. Izrazita vrednost in 'primerjalna prednost' je izjemen preplet različnih tipov krajine, celovitost pojavljanja kraških fenomenov, število in raznovrstnost habitatov, razširjenost naravnih vrednot glede na nadmorsko višino in lego v prostoru TNP, bogastvo flore in favne ter kulturna dediščina. Na osnovi teh razlogov je bilo ugotovljeno, da je TNP v evropskem merilu izjemen park (Svet Evrope 2004). Iz navedenega je razvidno, da TNP ni niti botanični eldorado, kot so ga romantično imenovali prvi snovalci TNP v začetku 20. st., in tudi ni enovit gozdni ali visokogorski svet. Je enkraten in neponovljiv alpski prostor $\mathrm{z}$ vsemi vrstami naravnih vrednot, $\mathrm{z}$ izjemno biodiverzitetno vrednostjo ter enkratno kulturno krajino z bogato kulturno dediščino. In kot takega smo dolžni TNP predstavljati vsem, ki jih park zanima, ga obiskujejo ali v njem živijo.

V strogem naravovarstvenem in krajinsko-ekološkem pogledu je pravzaprav vsaka še tako vzgojna, učinkovita in potrebna informacijska tabla na nek način moteča $\mathrm{v}$ prostoru. Zato je pri pripravi programov razmestitve, vsebine in postavitvah tabel potrebno posebej pozorno delo. Tudi število tabel se ne bo kar naprej povečevalo, pač pa bodo nekatere table sčasoma zamenjane, odstranjene, poskušalo se bo izboljšati funkcijo informacijske table v vsebinskem in oblikovnem smislu. Opremljanje parka za obisk, postavljanje in vzdrževanje informacijske infrastrukture je torej dinamičen proces, ki ima pri upravljanju zavarovanega območja izredno pomembno vlogo.

\section{Viri in literatura}

Anko, B. 2001: TNP - leta 2021. V: Dvajset let pozneje. 20 let zakona o Triglavskem narodnem parku. Bled.

Bibelriether, H. 2001: Triglavski narodni park - biser evropske naravne dediščine. V: Dvajset let pozneje. 20 let zakona o Triglavskem narodnem parku. Bled. 
Bizjak, J. 2001: Triglavski narodni park - Načrt upravljanja (strokovne podlage). Interno gradivo. Bled.

Eagles, P. 2001: International trends in park tourism. Paper prepared for EUROPARC 2001. Matrei.

Güthler, A., Kleinn, E., Knapp, H. D. 1998: The Management and protection of category II sites in Europe. V: Parks for Life 97. Gland.

Lah, A. 2001: Snovanje narodnega parka. V: Dvajset let pozneje. 20 let zakona o Triglavskem narodnem parku. Bled.

Larsson, T. B. 1993: Maintaining natural processes in ecosystems. V: Proceedings of the 1992 FNNPE General assembly and symposium on protecting ecosystems through natural succession. Grafenau.

Lukan Klavžer, T., Šolar, M. 1996: Varovanje in razvoj v Triglavskem narodnem parku: harmonija ali alternativa? Geografski obzornik 43, 3. Ljubljana.

McNelly, J., Thorsell, J., Ceballos-Lascurain, H. 1992: Development of national parks and protected areas for tourism. Madrid.

Piskernik, A. 1962: Zgodovina prizadevanj za ustanovitev Triglavskega narodnega parka. Varstvo narave 1. Ljubljana.

Pretner, M., Šolar, M. 2006: Mreža informacijskih mest v TNP. Bled.

Svet Evrope 2004: ResDip (2004) 11. Strasbourg.

Šolar, M. 2000: Pomen zavarovanih območij (parkov) za varstvo narave ter vloga Triglavskega narodnega parka $\mathrm{v}$ luči Zakona o ohranjanju narave in mednarodnih standardov za varstvo narave. Gozdarski vestnik 58, 5-6. Ljubljana.

Šolar, M. 2001: Informacijske table v Triglavskem narodnem parku. Proteus 63, 7. Ljubljana. Vidaković, P. 1997: Nacionalni parkovi u svijetu. Zagreb.

\section{PROVIDING VISITOR INFRASTRUCTURE IN THE TRIGLAV NATIONAL PARK IN THE LIGHT OF THE OBJECTIVES AND PURPOSES OF ESTABLISHING A NATIONAL PARK}

\section{Summary}

The exceptional value of the Triglav National Park (TNP) lies in the fact that the multitude and diversity of natural and cultural assets comprised in the territory of the Julian Alps in Slovenia, which is protected, almost in its entirety as the TNP, is unparalleled anywhere else in Europe. The park's outstanding value and comparative advantage is an interwoven pattern of landscape types, abundant karst phenomena, diversity of habitat types, distribution of valuable natural phenomena in terms of elevation and location within the TNP, richness of flora and fauna, and cultural heritage. These were also the grounds for recognizing TNP a park of European importance (Council of Europe 2004). It follows that TNP is neither a botanical eldorado, as it was romantically named by the initiators of the park at the dawn of the 20th century nor a uniform mountainous or high-altitude area. TNP is a unique area in the Alps boasting a plethora of natural values, outstanding biodiversity value, exceptional 
cultural landscape and rich cultural heritage. As such, TNP should be presented to all who are interested in the park, who visit it or reside within its borders.

When viewed in strict nature conservation terms and from the perspective of landscape ecology, each information board, regardless of how educational, efficient and necessary it may be, is intrusive to the natural environment. Because of the above, special attention is to be paid to planning the distribution and contents of the information boards as well as their installation. The number of information boards will not continue to increase; instead, some boards will be replaced in time, some removed, and efforts will be invested into improving their functionality in terms of both content and form. Visitor infrastructure and provision and maintenance of information infrastructure are dynamic processes that play a crucial role in protected area management. 